УДК [94 : 327] (549.1) «20»

DOI: https://doi.org/10.33782/eminak2019.4(28).356

\title{
РОЛЬ ПАКИСТАНУ У МІЖНАРОДНИХ ВІДНОСИНАХ НА ПОЧАТКУ ХХІ СТОЛІТТЯ
}

\author{
Ігор Горобець \\ Сумський державний педагогічний університет імені А.С. Макаренка (Суми, Україна) \\ e-mail: gorobech.igor@gmail.com \\ ORCID: https://orcid.org/0000-0002-2416-7898
}

У статті проаналізовано роль і місце Пакистану у сучасних міжнародних відносинах. Зазначається, що після оволодіння ядерною зброєю Пакистан позиціонує себе як держава, яка спромоглася встановити відносний воєнно-політичний паритет з Індією. Статус ядерної держави перетворив Пакистан на одного із лідерів ісламського світу. Водночас після терактів 11 вересня 2001 р. Пакистан, виходячи з політичних міркувань, підтримав антитерористичну операцію США у сусідньому Афганістані. Це дало можливість нейтралізувати негативні наслідки міжнародного режиму санкцій, який було запроваджено після ядерних випробувань 1998 року. Показано, що лише фактору ядерної зброї недостатньо для входження Пакистану у коло розвинутих держав сучасної системи міжнародних відносин.

Ключові слова: ісламський світ, тероризм, Пакистан, Південна Азія, ядерна зброя

Актуальність статті обумовлена потребою аналізу тенденцій розвитку сучасної системи міжнародних відносин на периферії глобальної світової системи. Цікавою $€$ проблема визначення факторів, які впливають на визначення місця та ролі Пакистану в ієрархії міждержавних відносин на рівні регіону Південної Азії й у глобальному світі.

Метою статті є аналіз діалектики взаємного впливу внутрішньополітичних процесів розвитку Пакистану та його позиціонування на міжнародній арені на початку XXI ст.

Огляд публікацій. На жаль, у вітчизняній історіографії фактично відсутня традиція глибоких досліджень історії та сучасності Пакистану. Варто згадати окремі праці українських індологів, які торкаються зазначеної проблематики. Однією з таких робіт є праця О.А. Барділовської. Авторка розглянула тенденції розвитку Пакистану, а також проаналізувала найважливіші проблеми історії взаємин двох найбільших держав Південної Азії - Індії та Пакистану. Зокрема, розглядаються тенденції впливу кашмірського конфлікту на безпеку у регіоні та на двосторонні індійськопакистанські відносини ${ }^{1}$. Серед інших наукових розробок можна також назвати роботу П.М. Ігнатьєва, присвячену країнознавчим аспектам історії Індії та певному контексту індійсько-пакистанських відносин ${ }^{2}$.

Натомість, у випадку з темою нашого дослідження, російська історіографія більш-менш вільна від упередженого ставлення до Пакистану, навіть незважаючи на тісні стратегічні російсько-індійські відносини. Правильного розуміння співвідношення сил у пакистанській політиці вимагала реальна політика, зокрема, під час

\footnotetext{
1 Барділовська О.А. Індія і Пакистан: інтелектуальна історія розлучення. Київ, 2018202 с.

2 Ігнатьєв П.М. Індія на шляху до лідерства в Південній Азії. Чернівці, 2006. 504 с.
} 
присутності радянських військ в Афганістані у 1979-1989 рр. Ситуація не змінилася після розпаду СРСР, коли Росія залишилася представленою у регіоні передусім завдяки партнерству з ключовим суперником Пакистану - Індією. Завдяки цьому у Росії існує академічна наукова школа досліджень Пакистану. Варто згадати праці В. Белокреницького, Ю.Ганковського, Р. Ланди. Зокрема, у монографії В. Белокреницького і В. Москаленко детально розглянуто внутрішньополітичні й окремі зовнішньополітичні аспекти розвитку Пакистану у ХX ст.3. У монографії Ю. Ганковського показано еволюцію політичної системи Пакистану на прикладі змін його трьох конституцій, починаючи від часів здобуття незалежності. Автор дійшов висновку, що демократичні традиції дуже складно вкорінюються на специфічному пакистанському грунті ${ }^{4}$. В. Москаленко у своїй монографії безпосередньо дослідив вплив внутрішньополітичного розвитку Пакистану, частої зміни цивільних і військових форм правління, на формування та еволюцію зовнішньої політики Пакистану5. 0. Плешов у своїй монографії показав складну діалектику впливу політичного ісламу на політичний режим у Пакистані та, відповідно, на ієрархію зовнішньополітичних і внутрішньополітичних пріоритетів Пакистануб. Звичайно, завдання диверсифікації зв'язків України з країнами Азї вимагає врахування здобутків світової історіографії досліджень історії Пакистану без чого неможливо розробити адекватну стратегію просування українських національних інтересів до Південної Азії.

12 жовтня 1999 р. голова Генерального штабу і головнокомандувач збройними силами Пакистану генерал Первез Мушарраф здійснив військовий переворот й усунув Н. Шарифа від влади. Лідери опозиції Беназір Бхутто та Наваз Шариф були вимушені емігрувати, відповідно до Лондону та Саудівської Аравії. Черговий військовий переворот був обумовлений традиційною повагою пересічних пакистанців до армії як найважливішого інституту держави7.

Здобувши вищу владу у Пакистані, Первез Мушарраф 15 грудня 1999 р. висунув програму реформ, які мали забезпечити стимулювання економічного розвитку та боротьбу з корупцією. Але масову свідомість завжди реформувати найскладніше. Безперечно, суттєвою перешкодою на шляху демократизації пакистанського суспільства залишається його традиціоналізм, міжетнічні та міжконфесійні проблеми. Військовий режим П. Мушаррафа не користувався великою суспільною підтримкою. Внаслідок дії комплексу об'єктивних і суб'єктивних причин пакистанські військові так і не змогли запропонувати форму «авторитаризму розвитку»8.

Більшість пакистанських мусульман переконані, що владна еліта не має права перетворити ісламську країну на світську державу. Але відразу після встановлення військового правління масові заворушення пішли на спад. Утім, вже 2000 р. економічні складності й етнічні проблеми спровокували нову хвилю терористичної активності. Збройні сили Пакистану так і не змогли роззброїти майже мільйон ісламістських бойовиків і військовий режим так і не здобув надійної соціально-політичної під-

\footnotetext{
3 Белокреницкий В.Я., Москаленко В.Н. История Пакистана. ХХ век. Москва, 2008. 576 с.

4 Ганковский Ю.В., Москаленко В.Н. Три конституции Пакистана. Москва, 1975. 125 с.

5 Москаленко В. Внешняя політика Пакистана. Формирование и основне этапы развития. Москва, 1984. С. 301.

6 Плешов О.В. Ислам, исламизм и номинальная демократия в Пакистане. Москва, 2003. 260 с.

7 Ахмедов В.М. Военные, власть и политический ислам на Ближнем и Среднем Востоке. Проблема региональной стабильности // Восток. 2006. № 3. С. 87.

8 Политическое цунами. Аналитика событий в Северной Африке и на Ближнем Востоке. Москва, 2011. С. 13.
} 
тримки. Пакистанські ісламісти довели, що можливості армії не всесильні.

У липні 2001 р. Мушарраф проголосив себе президентом. На відміну від інших пакистанських військових диктаторів, П. Мушарраф ніколи не ставив питання непридатності представницької демократії до умов Пакистану. Ця риторика допомогла Мушаррафу приєднатися до зусиль НАТО в Афганістані й отримати економічну допомогу від США. Запобігаючи посиленню впливу ісламістів на ядерні сили Пакистану, Мушарраф провів чистку в армії та серед фізиків-ядерників. Спецслужби Пакистану заарештувати 689 членів угруповання «Аль-Каїда», з яких 396 передали США, отримавши за це мільйони доларів. У 2004 р., демонструючи важливість американсько-пакистанських відносин, Вашингтон надав Ісламабаду статус основного союзника за межами НАТО. Але по мірі розвитку подій в Афганістані між США і Пакистаном почали накопичуватись протиріччя, оскільки США регулярно звинувачували Пакистан у недостатній активності у боротьбі з тероризмом. У відповідь Пакистан гостро критикував удари безпілотних літальних апаратів по цивільним цілям на території Афганістану, внаслідок чого гинули цивільні ${ }^{9}$.

Впродовж 1999-2002 рр. генерал П. Мушарраф правив Пакистаном в умовах режиму надзвичайного стану, хоча певний час формально на своїй посаді був обраний 1997 р. президентом М.Р. Тарар. У лютому 2002 р. судова влада Пакистану скасувала рішення уряду про створення спеціальних трибуналів за участі військових. Після референдуму 30 квітня 2002 р. він збирався «будувати демократію на принципах ісламу»10. Зазначимо, що Пакистан є єдиною ядерною державою серед 56 країн, які беруть участь у діяльності міжурядової «Організації ісламська конференція». Ії̈ головною метою $є$ зміцнення ісламської солідарності, консолідація зусиль мусульманських держав, розробка єдиних підходів до актуальних проблем сучасності в інтересах і на користь ісламських народів.

Суттєвим фактором дестабілізації становища є економічні особливості розвитку Північно-Західної прикордонної провінції Пакистану. За величиною території вона займає четверте місце серед адміністративних територій Пакистану, але за щільністю населення друга після Пенджабу. Однак розташований у північно-західній частині Індо-Гангзької низини Пенджаб є житницею Пакистану, його найбільш економічно розвиненою областю. Більша частина провінції Вазіристан вкрита високими горами. Це зробило провінцію важливим постачальником електроенергії для решти країни. Однак навіть відносно дешева електроенергія не дає можливістю забезпечити роботою більшість населення провінції. Провінція $є$ центром місцевої «тіньової» економіки. Навіть тривала присутність на цій території загонів і баз пакистанської армії лише частково дала можливість модернізувати інфраструктуру ПівнічноЗахідної прикордонної провінції Пакистану, яка загалом далека від середніх по країні стандартів ${ }^{11 .}$

10 жовтня 2002 р. в Пакистані відбулися вибори до нижньої палати парламенту, в яких було заборонено брати участь як Б. Бхутто, так і Н. Шарифу. У підсумку жодна 3 62 партій не здобула більшості. Але за результатом парламентських виборів фундаменталістська коаліція ісламістських партій «Муттахіда Маджлис Амаль» (Об’єднана рада дії) стала основною опозиційною силою до режиму військових. Загалом ісламі-

\footnotetext{
9 Пакистан: за рамками стереотипов / Под ред. Борисова Т.И., Макиенко К.В. Москва, 2019. С. 29. 10 Москаленко В.Н. Политическая ситуация в Пакистане // Пакистан, страны Южной Азии и Среднего Востока. История и современность. Москва, 2004. С. 53.

11 Эльянов А.Я. Развивающиеся страны в контексте глобализации // Восток. 2004. № 2. С. 80.
} 
стські партії здобули 45 з 272 місць у Національній асамблеї. Після виборів 2002 р. президент П. Мушарраф провів через парламент сімнадцяту поправку до Конституції, яка наділила президента не лише правом розпускати уряд і парламент, а й широкими зовнішньополітичними повноваженнями ${ }^{12}$.

Введення 19 березня 2003 р. американських військ до Іраку стало додатковим приводом для посилення антиамериканських настроїв у Пакистані. У 2004 р. у високогірних районах «вільного Пуштуністану» та у долині Сват організаційно оформився екстремістський рух «Техрік-е талібан Пакистан», тобто «Рух талібів Пакистану». Навесні 2005 р. пакистанський уряд прийняв рішення про вилучення важких озброєнь у «зоні племен». Пуштунів, які мешкають на пакистансько-афганському кордоні, закликали здати кулемети, гранатомети, реактивні снаряди, протитанкові ракети, аби не допустити їхнього потрапляння до рук бойовиків. Пуштунам залишили лише ручну стрілецьку зброю13.

У лютому 2006 р. Талібан і «Аль-Каїда» оголосили про створення Ісламської держави Вазіристан у зоні пуштунських племен на прикордонні між Афганістаном і Пакистаном. Під загрозою опинився транзит вантажів для солдат контингенту НАТО в Афганістані через Хайберський прохід. Він розташований у 17 км західніше Пешавару. Його довжина 53 км, ширина 3-5 км, причому на протязі 8 км ширина проходу не перевищує 180 метрів. У спробі замирення із мусульманськими радикалами президент П. Мушарраф був вимушений призупинити реформу шаріатського законодавства. Утім, саме за правління Мушаррафа дещо були розширені права не мусульманських громадян Пакистану, так само як і пакистанських жінок.

У травні 2007 р. Карачі й інші мегаполіси Пакистану охопили чергові криваві сутички між сунітами та шиїтами. Крім того, таліби у цей час встановили контроль над долиною Сват у Північно-Західній прикордонній провінції Пакистану. Внаслідок цього пакистанська армія була вимушена втягнутися у афганську війну14. Ескалація співпала із загальним страйком, який проводила опозиції, намагаючись домогтися відставки П. Мушаррафа. 10-12 липня 2007 р. після тривалого протистояння мусульманських клерикалів і військових властей останні штурмом взяли Лал Маджід (Червону мечеть) і два медресе. Медресе Джамія Хафса було відоме у Пакистані як головний осередок прихильників встановлення ісламістського режиму правління. Події навколо мечеті лише активізували терористичну активність по всьому Пакистану. Активність ісламістів засвідчила провал спроб П. Мушаррафа зробити світську освіту пріоритетом у боротьбі з тероризмом. Адже Пакистан на той час займав 160те місце серед 175 країн світу за рівнем освіти. Пакистанським військовим було дуже важко пояснити пересічним пакистанцям, чому вони воюються проти талібів - «захисників ісламу» 15 .

18 жовтня 2007 р. після восьми років вигнання до Пакистану прибула Беназір Бхутто. За умови збереження Мушаррафом посади президента, вона збиралася стати прем'єр-міністром ${ }^{16}$. Але виконання цих умов потребувало надто багато «якби». В

\footnotetext{
12 Тыссовский Ю.К. «Крестоносцы» против ислама. Москва, 2011. Т. 1. С. 80.

13 Воробьев В.В. Дело Асии Биби // Азия и Африка сегодня. 2011. № 9. С. 45.

14 Викрам Суд. Радикальный ислам в регионе и его влияние на Южную Азию // Радикальный ислам. Взгляд из Индии и России. Москва, 2010. С. 14-15.

15 Суворова А.А. Беназир Бхутто: последние дни // Азия и Африка сегодня. 2010. № 11. С. 27.

16 Федоров В. Опора на армию: «авторитаризм развития» и «авторитаризм стагнации» // Азия и Африка сегодня. 2000. № 5. С. 16.
} 
листопаді 2007 р. П. Мушарраф відправив у відставку членів Верховного Суду, яка ставили під сумнів його законодавчі повноваження. Первез Мушарраф опинився перед непростим вибором між демократизацією, ісламізацією та військовим правління. Але ударом у відповідь по позиціям самого Мушаррафа стало вбивство під часі мітингу у м. Равалпінді 27 грудня 2007 р. Беназір Бхутто. Спроба Мушаррафа розміняти повернення Бхутто на свій черговий президентський термін зазнала провалу. Епілогом цієї події можна вважати слова самої Беназір, яка визнавала, що «як квітка не може розквітнути у пустелі, так і політичні партії не можуть розвиватися за тоталітарного режиму. Якщо політичні партії зуміли вижити і зміцнитися, всупереч драконівським заходам проти них, це заслуга тих, хто віддав життя в ім'я демократії, i заслуга пакистанського народу, який розуміє, що зможе відновити свої права, лише об'єднавшись у національну партію»17.

У березні 2008 р. прем'єр-міністром Пакистану став прихильник Бхутто Юсуф Реза Гілані. Він вкотре зіштовхнувся з проблемою нерівномірності розвитку регіонів Пакистану. Це стимулювало додаткові етнонаціональні конфлікти та протиріччя. Крім того, влітку 2008 р. президент США Дж. Буш молодший підписав директиву, яка санкціонувала американські таємні наземні операції проти талібів на території Пакистану ${ }^{18}$.

18 серпня 2008 р., перебуваючи під загрозою імпічменту, П. Мушарраф залишив посаду президента Пакистану. Новим главою держави став чоловік Беназір Бхутто А.А.Зардарі, який за часи їхнього шлюбу 11 років відсидів у пакистанських в'язницях. Після цього у країні розгорнулася запекла внутрішньополітична боротьба за черговий перерозподіл влади. Попри інтереси глобальної безпеки, Пакистан залишався внутрішньо нестабільною державою. Пакистан залишається у становищі периферії, яка постачає більш успішні капіталістичні економіки сировиною і дешевою, найчастіше нелегальною, робочою силою. Суттєвий вплив на системну кризи державних інститутів Пакистану має продовольча криза, яка набирає обертів під впливом світової фінансової кризи після 2008 року19.

Російський дослідник В.Я.Белокреніцький слушно звертає увагу на масштабні диспропорції, які роблять Пакистан «провальною державою». Насамперед, це величезна кількість населення. У 2009 р. пакистанців було 175 млн. чоловік. Водночас дедалі відчутнішим ставав дефіцит ресурсів. На фоні посилення соціальних диспропорцій загострювалися етнорелігійні протиріччя. У Пенджабі проживає більше половини населення країни - 56\%, у провінції Сінд - 23\%, у Північно-Західній прикордонній провінції - 13\% пакистанців, а у сепаратистськи налаштованій провінції Белуджистан лише 5\%, населення столичного округу Ісламабад наближається до $1 \%$ від загальної чисельності пакистанців ${ }^{20}$.

20 вересня 2008 р. радикальні ісламісти підірвали розкішний міжнародний готель «Марріот» в Ісламабаді. Це дало привід командуючому пакистанською армією генералу Ашфаку Первезу Кайяні звільнити керівника розвідки ISI генераллейтенанта Надіма Таджа. Його наступником став родич президента Мушаррафа

\footnotetext{
17 Беназир Бхутто. Дочь Востока. Москва, 1991. С. 38.

18 Искандаров А.А. Исламский сектор банковской системы Пакистана // Азия и Африка сегодня. 2011. № 4. С. 24.

19 Пахомов Е. Битва при Красной мечети // Огонек. 2007. № 29. С. 113.

20 Жмуйда И.В. Экономика Северо-Западной Пограничной провинции Пакистана и ее особенности // Пакистан, страны Южной Азии и Среднего Востока. Москва, 2004. С. 14.
} 
Ахмед Шуджаа Паша. Але він дискредитував себе вже 26 листопада 2008 р., коли пакистанські ісламісти скоїли теракт в індійському м. Мумбаї. Навіть тодішній державний секретар США К. Райс звинуватила у цьому офіційну владу Пакистану.

Суттєво погіршила становище Пакистану світова економічна криза. Спочатку функціонування у Пакистані «ісламського сектору банківських послуг», для якого властива заборона на кредитний процент, частково захистило ісламські банки від західної кризи 21.

16 грудня 2009 р. Верховний Суд Пакистану відновив судове переслідування колишніх корумпованих чиновників. 17 квітня 2010 р. обидві палати парламенту Пакистану прийняли вісімнадцяту поправку до Конституції, якою повернули країну до парламентської форми правління, а 19 квітня 2010 р. вона набула чинності. Головою виконавчої влади став прем'єр-міністр. Відтоді прем'єр-міністр формував засади зовнішньої політики та ніс за неї відповідальність.

За президентом залишили важливі зовнішньополітичні представницькі функції, але позбавили права призначати губернаторів, командувати збройними силами, розпускати центральний і регіональні уряди. Розпускати парламент тепер президент мав лише за рекомендацією прем'єр-міністра. Тоді також було здійснено адміністративне перейменування «Північно-Західної Прикордонної провінції», яка тепер має назву Хайбер-Пахтунхва 22.

У Пакистані міністр закордонних справ, на відміну від Індії, не є другим за рангом міністром уряду, але належить до кола найважливіших міністрів. Керівництво апаратом МЗС Пакистану здійснює кадровий дипломат, який відповідає за ведення переговорів із Індією та курує відносини Пакистану з Асоціацією регіонального співробітництва країн Південної Азії.

Потужний удар по міжнародному іміджу і внутрішній безпеці Пакистану завдала «справа Асії Бібі», яка розпочалася у червні 2009 р. Християнка А. Бібі була звинувачена мусульманками в образі ісламу. Захистити їі не змогли і пакистанські ліберали. Тож «справжній іслам» залишається перешкодою на шляху ствердження у Пакистані демократичних порядків 23 . Окрім того пакистанська армія увесь цей час перебуває у стані громадянської війни з власними ісламістами.

У січні-березні 2011 р. Пакистан стурбовано слідкував за подіями «арабської весни», тобто за суперечливим процесом зміни правлячих режимів у більшості арабських країн. 17 січня 2011 р. здійснилася «жасминова революція» у найбільш європеїзованій країні Магрибу Тунісі. 11 лютого 2011 р. у відставку пішов президент Єгипту з 1981 р. Х. Мубарак. Цю подію президент США Б. Обама порівняв з падінням берлінського муру. 15 лютого 2011 р. розпочалися масові протести у Лівії і вже 23 березня 2011 р. сили НАТО та Ліги арабських держав бомбували позиції Каддафі. У форматі проекту «глобальної демократичної революції» 29 березня 2011 р. розпочалися заворушення у Сирії. Участь у цих подіях беруть пакистанські таліби.

Громадянська війна в Ємені становить небезпеку для союзних Пакистану Саудівської Аравії та Султанату Оман, де працюють чимало вихідців з Пакистану. Проте не треба забувати, що й пакистанська армія це лише віддзеркалення суспільства, в якому вона існує та діє. Помірковані ісламісти проникають в армію та спецслужби,

\footnotetext{
21 Малышева Д. Исламско-фундаменталистский проект в реалиях современного мира // Мировая экономика и международные отношения. 1999. № 7. С. 24.

22 Тыссовский Ю.К. «Крестоносцы» против ислама. Москва: Наука, 2011. Т. 1. С. 118.

23 Воробьев В.В. Дело Асии Биби // Азия и Африка сегодня. 2011. № 9. С. 45.
} 
тому більш вірогідним буде варіант політичного діалогу з поміркованими ісламістами зі спорадичною війною проти радикалів. Лише на початку липня 2012 р. Пакистан в обмін на термінову фінансову допомогу США у розмірі 1,1 млрд. дол. погодився відновити транзит для сил НАТО в Афганістані. Зроблено це було на фоні протестів пакистанських радикальних ісламістів. 12 липня 2012 р. Верховний Суд Пакистану зажадав від прем'єр-міністра Раджі Первеза Ашрафа передати до суду корупційні справи президента Алі Асіфа Зардарі.

Наприкінці грудня 2012 р. з нагоди п’ятої річниці вбивства Беназір Бхутто з першою політичною промовою виступив ії 24-річний син Біловал Бхутто Зардарі, що вважалося початком його політичної кар'єри. В адміністративному центрі провінції Белуджистан місті Кветта 11 січня 2013 р. шиїти смертники здійснили терористичний акт, за наслідками якого загинули 115 людей. За день до цього у теракті, організованому сепаратистською «Об’єднаною армією белуджів» загинули ще 40 людей 24. Індійський науковець Вікрам Суд відверто називає пакистанську армію «з її колосальними корпоративними інтересами» головним провідником не лише пакистанської індійської й афганської політики, «контролером ядерної сфери, захисницею віри й держави, а й економічним власником країни». На його думку, «у пакистанській армії є два типи офіцерів: націоналістичні джихадісти та ісламістські джихадісти»25.

Головним інструментом відтворення ісламізму є система освіти Пакистану. «Військово-розвідувальна каста» Пакистану диференціюється за своїми зовнішньополітичними орієнтирами. Одна частина орієнтується на США, інша на Китай. Ісламський світ надто розколотий, аби на рівних протистояти Заходу. Стабільний авторитаризм у Пакистані так і не створив навіть передумов для формування консолідованого демократичного режиму.

Натомість гостра внутрішньополітична криза у Пакистані доповнювалася паралічем цивільних структур влади, а глибока соціально-економічна криза органічно доповнювалася неефективною національною стратегію розвитку Ісламської Республіки Пакистан. Надто ризикованою виглядає тактика використання терористичних угруповань з метою досягнення геополітичних переваг над Індією. Адже пакистанська державність залишається привабливою мішенню для антисистемних сил.

15 січня 2013 р. Верховний Суд Пакистану постановив заарештувати прем'єрміністра країни Раджі Первеза Ашрафа, якого звинуватили у отриманні хабарів за часів перебування на посаді міністра енергетики. Того ж дня в Ісламабаді сталися масові заворушення, організовані богословом Тахіром Кадрі, який заперечував, що його підтримують пакистанські військові. За даними Світового банку, у Пакистані на 1-2 долари в день живуть 84,7\% населення. Пакистан не має ані ефективної ринкової економіки, ані ефективних державних структур 26.

Додаткове напруження між центральними властями Пакистану та пуштунами провокує будівництво Калабазької греблі, яка загрожує екологічною катастрофою для Північно-Західної Прикордонної провінції. Американська операція в Афганістані перетворила талібів на єдиних представників пуштунів, які у перспективі можуть створити Пуштуністан. Пакистанські ісламісти вважають за потрібне навести порядок, тобто усунути «неправедних правителів», які сіють соціальну несправедливість,

\footnotetext{
24 Внешнеполитический процесс в странах Востока / Под ред. Д.В. Стрельцова. Москва, 2011. С. 79. 25 У Белуджистані триденна жалоба // Голос України. 2013. 13 січня. С. 7.

26 Эльжанов В. Решение пакистанского правительства об изъятии тяжелого вооружения в «зоне племен» // Зарубежное военное обозрение. 2005. № 4. С. 66.
} 
займаються корупцією та деморалізують мусульман. Особливий інтерес у цьому сенсі становлять екстремістські неурядові релігійно-політичні організації. Пакистан, зважаючи на інтенсивне поширення антизахідних та антиамериканських суспільних настроїв, перетворюється на центр їхньої діяльності27. Тому ісламський фундаменталістський проект залишається актуальною альтернативою існуючому політичному режиму у Пакистані. Радикальні пакистанські ісламісти продовжують розглядати модернізаційну глобальну активність Заходу як продовження практики хрестових походів.

Основними конкурентами на виборах 11 травня 2013 р. була партія «Мусульманська ліга» Наваза Шаріфа та партія гравця у крикет Імран Хана. Пакистанські таліби назвали вибори антиісламським актом і перешкоджали голосуванню жінок. Зрештою, переконливу перемогу на виборах здобула партія «Мусульманська ліга» на чолі з Навазом Шарифом. Виступаючи перед новим складом парламенту 25 червня 2013 р. прем'єр-міністр Пакистану Н. Шариф заявив, що Первез Мушарраф буде підданий суду за звинуваченнями у скоєнні військового перевороту 13 жовтня 1999 р. та за підозрою у потуранні вбивцям Беназір Бхутто.

Американський політолог індійського походження Параг Жанна прогнозує, що за наступні двадцять років населення Пакистану виросте до 200 млн. осіб і «цю масу не зможуть утримати під контролем навіть військові», адже «як за демократії, так і за диктатури, народ звик до корупції і відсталості».У липні 2013 р. цю тезу підтвердила лондонська поліція, яка звинуватила членів пакистанського «Об’єднаного національного руху» у відмиванні 600 тис. доларів.

Надзвичайно складною залишалася ситуація у пакистанські економіці. Попри повідомлення про участь пакистанських ісламістів на боці сирійської опозиції у громадянській війні у Сирії, у влади Пакистану навряд чи були підстави сподіватися на «експорт» своїх радикалів на Близький Схід. Адже, повернувшись звідти, вони набудуть ще більший досвід війни та загартовуються у своєму непримиренному радикалізмі. У липні 2013 р. пакистанські спецслужби розкрили підготовку декількох замахів на життя прем'єр-міністра Наваза Шарифа, які готували пакистанські таліби.

30 липня 2013 р. пакистанські парламентарі обрали новим президентом Пакистану члена партії «Мусульманська ліга» прем'єр-міністра Н. Шарифа Мамнуна Хусейна. Своєрідно цю подію відзначили пакистанські таліби, які того ж дня у результаті збройного нападу на в'язницю звільнили понад дві сотні своїх соратників. Але це не завадило США та Пакистану офіційно відновити «стратегічний діалог» 3 проблем безпеки. У Пакистані з'явився перший мультсеріал «Месниця в паранджі», де молода вчителька бореться з талібами, які намагаються закрити школу для дівчаток.

Завершення на початку серпня 2013 р. священного для мусульман місяця Рамадан не зменшило рівня терористичної активності у Пакистані. 9 серпня 2013 р. у столиці Белуджистану м. Кветта була розстріляна сунітська мечеть. Уряд Наваза Шарифа мав обмежені матеріальні, політичні, силові й інформаційні ресурси для протистояння внутрішньому тероризму, який був симптомом глибокої системної кризи існуючої форми пакистанської державності. Серйозними викликами для внутрішньої безпеки Пакистану залишаються фактично усі основні види тероризму:

\footnotetext{
27 Белокреницкий В.Я. Пакистан - «провальное государство» в Азии? // Азия и Африка сегодня. 2009. № 11. C. 14.
} 
державний, міжнародний, релігійний і, навіть, ядерний.

13 серпня 2013 р., перебуваючи у Пакистані, Генеральний секретар ОOH Пан Гі Мун закликав до міжнародно-правового врегулювання проблеми використання на території Пакистану американських безпілотних літаків-дронів. Не дивно, що із західної точки зору «ісламізм - це не хвороба ісламу, це його традиційна реакція на програну історію». Н. Шарифу важливо було зміцнити союзницькі відносини зі США, оскільки останні докладають зусилля з метою «модернізації» пакистанських медресе, ведуть інформаційну війну з радикальними ісламістами в Інтернеті тощо. Одним із проявів подібної інформаційної війни стала блокада першого в історії Пакистану сайту місцевих геїв.

9 вересня 2013 р. завершився термін перебування на посаді президента А.А. Зардарі, якому вдалося повністю відбути конституційний президентський термін. Серйозним викликом для модернізації пакистанського суспільства $є$ той факт, що воно продовжує жити за законами спорідненості та віри. У неділю 22 вересня 2013 р. у Пешаварі таліби здійснили вибух у християнській церкві, що підтвердило хронічний характер проблем внутрішньої безпеки Пакистану.

Наприкінці правління президента США Б. Обами (2014-2016 рр.) Вашингтон фактично «заморозив» відносини з Пакистаном. Натомість були спроби активізувати американсько-індійські відносини. Президент США Д.Трамп упродовж 20172019 рр. визнав Пакистан не стільки союзною державою у регіоні Південної Азії, скільки проблемною країною. За цих обставин головним стратегічним союзником Пакистану стала Саудівська Аравія. Певне «розморожування» пакистанськоамериканських відносин спостерігалося після візиту наприкінці липня 2019 р. до Вашингтону президента Пакистану Імран Хана. Індія своєрідно відреагувала на цю тенденцію. Напруга у Кашмірі спостерігалася впродовж тривалого часу, але стала особливо гострою після рішення прем'єр-міністра Індії Нарендри Моді скасувати автономний статус індійської частини штату Джамму і Кашмір. Це викликало прогнозовано гостру реакцію Пакистану.

Переростанню кризи у чергову пакистансько-індійську війну поки що перешкоджають зусилля США, Російської Федерації, Євросоюзу, Китаю. Усі великі гравці сучасної системи міжнародних відносин продемонстрували незацікавлення у переході застарілого індійсько-пакистанського конфлікту навколо Кашміру у військові дії між двома ядерними державами. Але ситуація залишається непевною, адже ключова зовнішньополітична проблема Пакистану, якою $є$ возз'єднання обох частин Кашміру, не вирішена. Причому трагедія полягає у тому, що вирішити їі мирним шляхом фактично неможливо, а від війни «гарячі голови» стримують військово-політична й економічна асиметрія потенціалів Індії та Пакистану, ризики того, що гіпотетична війна усуне від влади правлячі в обох країнах еліти та спровокує подальший територіальний розпад цих найбільших країн Південної Азії.

Висновки. Головну проблему пакистанської авторитарної модернізація досить влучно сформував сінгапурський реформатор Лі Куан Ю, який констатував, що найбільшим питанням для авторитарної модернізації є якість головного модернізатора. Досі таким «модернізатором» намагалась виступати пакистанська армія, але вона за своїми ціннісними орієнтирами та суспільними функціями не може забезпечити органічну цивільну модернізацію. Наявність сильних лідерів у Пакистані завжди послаблювала демократичні інститути, які й без того не мають стабільної соціальної підтримки. Загрозливо виглядає розчарування більшості пакистанського суспільст- 
ва у націоналістичному режимі військових, який не може забезпечити стабільного зростання економіки, захисту прав людини, політичних свобод. Натомість пакистанські ісламісти намагаються в міру своїх можливостей вести боротьбу з клановими та корупційними традиціями, які історично вкоренилися у Пакистані. Правда, «ісламістська модель» також не може примирити сунітську більшість і шиїтську меншість у структурі пакистанського суспільства. Внаслідок домінування цих тенденцій сучасний Пакистан опинився у «глухому куті» свого розвитку.

\section{REFERENCE}

Ahmedov, V.M. (2006). Voennyie, vlast i politicheskii islam na Blizhnem i Srednem Vostoke. Problema regionalnoi stabilnosti [Soldiery, power and political Islam on fellow Creature and Middle East. Problem of regional stability]. Vostok, 3, 87 [in Russian].

Bardylovska, 0.A. (2018). Indiia i Pakistan: intelektualna istoriia rozluchennia [India and Pakistan: intellectual history of divorce]. Kyiv: Instytut skhodoznavstva imeni A.Yu. Krymskogo NAN Ukrainy [in Ukrainian]

Belokrenickiy, V.Ya., Moskalenko, V.N. (2008). Istoriia Pakistana. XX vek [History of Pakistan. XX age]. Moskva: Institut vostokovedeniia RAN [in Russians].

Belokrenitskiy, V.Ya. (2009). Pakistan - «provalnoe gosudarstvo» v Azii? [Is Pakistan the «failure state» in Asia?]. Aziia i Afrika segodnia, November 14 [in Russian].

Benazir Bhutto (1991). Doch vostoka [Daughter of the East]. Moskva: Politizdat [in Russian].

Borisov, T.I., Makienko, K.V. (2019). Pakistan: za ramkami stereotipov [Pakistan: after the scopes of stereotypes]. Moskva: Tsentr analiza strategiy i tekhnologiy [in Russian].

Elzhanov, V. (2005). Reshenie pakistanskogo pravitelstva ob iziatii tiazheloho vooruzheniia v «zone plemen» [The decision of the Pakistani government to withdraw heavy weapons in the «tribal zone»]. Zarubezhnoe voennoe obozrenie, 4, 66 [in Russian].

Elianov, A.Ya. (2004). Razvivaiuschiesia strany v kontekste globalizatsii [Developing countries in the context of globalization]. Vostok, 2, 94 [in Russian].

Fedorov, V. (2000). Opora na armiiu: «avtoritarizm razvitiia» i «avtoritarizm stagnatsii» [Reliance on the army: «authoritarianism of development» and «authoritarianism of stagnation»]. Aziia i Afrika segodnia, 5, 16. [in Russian].

Ignatiev, P.M. (2006) Indiia na shliakhu do liderstva v Pivdennii Azii [India is on a way to leadership in South Asia]. Chernivtsi: Knyhy - XXI [in Ukrainian].

Iskandarov, A.A. (2011). Islamskiy sektor bankovskoi sistemy Pakistana [Islamic sector of the banking system of Pakistan]. Aziia i Afrika segodnia, 4, 24. [in Russian].

Malysheva, D. (1999). Islamsko-fundamentalistskiy proekt v realiiah sovremennogo mira [Islamic fundamentalist project in the realities of the modern world]. Mirovaia ekonomika i mezhdunarodnye otnosheniia, 7, 108-117 [in Russian].

Moskalenko, V. (1984). Vneshniaia politika Pakistana. Formirovanie i osnovnye etapy razvitiia [Foreign policy of Pakistan. Formation and main stages of development]. Moskva: Nauka [in Russian].

Moskalenko, V.N. (2004). Politicheskaia situatsiia v Pakistane [Political situation in Pakistan]. In Pakistan, strany Yuzhnoi Azii i Srednego Vostoka. Istoriia i sovremennost (pp. 50-60). Moskva: Institut vostokovedeniia RAN [in Russian].

Pakhomov, E. (2007). Bitva pri Krasnoy mecheti [Battle near of the Red Mosque]. Ogonek, 29, 13 [in Russian].

Pleshov, 0.V. (2003). Islam, islamizm i nominalnaia demokratiia $v$ Pakistane [Islam, Islamism and nominal democracy in Pakistan]. Moskva: Institut vostokovedeniia RAN [in Russian].

Politicheskoe tsunami. Analitika sobytii v Severnoi Afrike i na Blizhnem Vostoke (2011). [Political tsunami. Analytics in North Africa and the Middle East]. Moskva: Institut vostokovedeniia RAN [in Russian].

Savchenko, D. (2009). AF-PAK: samyi goriachii raion na planete [AF-PACK: the hottest area on the planet]. Mirovaia ekonomika i mezhdunarodnye otnosheniia, 11, 14-15 [in Russian].

Streltsov, D.V. (2011). Vneshnepoliticheskii protsess v stranakh Vostoka [Foreign Policy Process in the East]. Moskva: Nauka [in Russian].

Sud, Vikram (2010). Radikalnyi islam v regione i ego vliianie na Yuzhnuiu Aziiu [Radical Islam in the region and its influence on South Asia]. In Radikalnyi islam. Vzgliad iz Indii i Rossii (pp. 50-86). Moskva: MOF-ETC [in Russian]. 
Suvorova, A.A. (2010). Benazir Bhutto: poslednie dni [Benazir Bhutto: The Last Days]. Aziia i Afrika segodnia, 11, 53 [in Russian].

Tyissovskii, Yu.K. (2011). «Krestonostsy» protiv islama [«Crusaders» against Islam]. Moskva: Nauka [in Russian].

Vorobev, V.V. (2011). Delo Asii Bibi [Asiia Bibi case]. Aziia i Afrika segodnia, 9, 45 [in Russian].

Zhmuida, I.V. (2004). Ekonomika Severo-Zapadnoi Pogranichnoi provintsii Pakistana i eio osobennosti [Economy of the North-West Frontier Province of Pakistan and its features] In Pakistan, strany Yuzhnoy Azii i Srednego Vostoka (pp. 170-182). Moskva: Institut vostokovedeniya RAN [in Russian].

\section{Ihor Horobets}

(Sumy State Pedagogical University named after A.S. Makarenko, Sumy, Ukraine)

ORCID: https://orcid.org/0000-0002-2416-7898

\section{Pakistan's Role in International Relations at the Beginning of the $21^{\text {st }}$ Century}

The role and place of Pakistan in contemporary international relations are analyzed in the paper. It is noted that, after gaining nuclear weapons, Pakistan has been considering itself a state that has managed to establish relative military-political parity with India. The status of a nuclear power has made Pakistan one of the leaders of the Islamic world. At the same time, after the September 11, 2001, terrorist attacks, Pakistan supported, for political reasons, the US counter-terrorism operation in neighboring Afghanistan. That made it possible to neutralize the negative effects of the international sanctions regime, introducing after the 1998 nuclear tests.

It is shown that the nuclear factor alone is not enough for Pakistan to enter the circle of developed states of the modern system of international relations. A considerable impediment to the democratization of Pakistan society remains its traditionalism, inter-ethnic and interconfessional problems. The military regime has not gained much public support. The majority of Pakistani Muslims are convinced that the ruling elite have no right to convert the Islamic state into a secular state.

The military regime never received reliable social and political support. It was during the governing of the military that the rights of non-Muslim citizens of Pakistan, as well as Pakistani women, were somewhat broadened. Pakistan Islamists have proven that the capabilities of the army are not all-powerful. Pakistan is the only nuclear power among the 56 states participating in the activities of the intergovernmental Organization of the Islamic Conference. Its main goal is to strengthen Islamic solidarity, to consolidate the efforts of Muslim states, to develop unified approaches to current issues of modernity in the interests and for the benefit of Islamic peoples. Pakistan remains an internally unstable state. Ethnic and religious contradictions are exacerbating against the background of increasing social imbalances. The Islamic fundamentalist project remains an actual alternative to the existing political regime in Pakistan. Radical Pakistan Islamists continue to consider the West's modernizing global activity as a continuation of the crusades. The «Islamite model» also cannot reconcile the Sunni majority and the Shiite minority in the structure of Pakistan society. Due to the dominance of these trends, modern-day Pakistan has found itself in a «deadlock» of its development.

Keywords: Islamic world, terrorism, Pakistan, South Asia, nuclear weapons 